\title{
PRODUCTION OF BIO-GASOLINE FROM CATALYTIC PYROLYSIS OF CANDLENUT OIL BIODIESEL (Aleurites moluccana) AND POLYSTYRENE WASTE MIXTURE
}

\author{
A. Nurfitriyah, Y. Kusumawati and H. Juwono ${ }^{\bowtie}$ \\ Department of Chemistry, Faculty of Science and Data Analytics, Institut Teknologi Sepuluh \\ Nopember, Surabaya-60111, Indonesia \\ Corresponding Author: hjachmad@gmail.com
}

\begin{abstract}
The production of bio-gasoline from candlenut oil biodiesel (Aleurites moluccana) and polystyrene waste mixture has been successfully carried out through the catalytic pyrolysis process. Al-MCM-41 : ceramics (7:3) is used as the catalyst in the pyrolysis process at the reaction temperature of $300^{\circ} \mathrm{C}$. This study evaluated the effect of feedstock ratios on the gasoline fraction $\left(\mathrm{C}_{7}-\mathrm{C}_{12}\right)$ and the physical properties of the fuel blend. The chromatogram of GC-MS analysis confirmed that the bio-gasoline obtained from the feedstock ratio of 1:1 gives the highest gasoline fraction $(81.17 \%)$. Moreover, the result of the physiochemical analysis showed that the fuel blend from the feedstock ratio of $1: 1$ has a high calorific value $(16.663 \mathrm{kcal} / \mathrm{kg})$ and octane number (100.5).
\end{abstract}

Keywords: Catalytic Pyrolysis, Candlenut Oil Biodiesel, Polystyrene, Al-MCM-41/ceramics, Liquid Hydrocarbon, Gasoline Fraction.

RASĀYAN J. Chem., Special Issue, 2021

\section{INTRODUCTION}

The thermochemical route for biomass-based fuel production, which possesses a great potential to be developed, is catalytic pyrolysis. ${ }^{1}$ Pyrolysis is regarded as the most promising technology because it can produce liquid fuel with high yield in a single step..$^{2-4}$ One of the biomass sources that can be developed as biofuel is candlenut oil (Aleurites moluccana).

Candlenut oil is non-edible, has abundant seed production, and a high share of oil content in their seeds that reaches 55-66\%. ${ }^{5}$ Previous studies revealed that biofuel generated from catalytic pyrolysis of candlenut oil has a high heating value $(10.705 \mathrm{kcal} / \mathrm{kg})$ and octane number (RON 124.7), which make it beneficial for alternative fuel. However, the heavy fraction of hydrocarbon in the obtained biofuel has a higher percentage than the light fraction, so that they are more suitable for biodiesel utilization. ${ }^{6-7}$ Gasoline must have a light fraction of hydrocarbons $\left(\mathrm{C}_{7}-\mathrm{C}_{12}\right)$ consisting of branched alkane, aromatic, or alicyclic other than heavy straight-chain alkane to meet with application requirements. Hence, co-feeding materials that have high moieties were required to enhance the cracking process. ${ }^{8-11}$

The addition of polystyrene plastic waste as co-feeding material in catalytic pyrolysis of biomass looks like a promising solution to enhance the properties of biofuel. ${ }^{12}$ Plastic waste can act as a hydrogen source during the cracking process to reduce the coke formation and thus increase the liquid fuel yield ${ }^{13-15}$ Polystyrene (PS) wastes also have aromatic moieties that can contribute to the high calorific value of the liquid fuel. ${ }^{16,17}$ Several studies have investigated the pyrolysis of biomass with polystyrene plastic wastes. Catalytic co-pyrolysis of black-liquor lignin with different plastics revealed that polystyrene produced the maximum yield of desired compounds, mainly aromatics $(55.3 \%) .{ }^{18}$ The presence of polystyrene in the co-pyrolysis of grape seeds also caused a considerable improvement in the organic phase yield and biofuel properties, which particularly reflected in the lower oxygen content and higher heating value. ${ }^{17}$ In another work, a better quality of biofuel and higher aromatics yield were achieved with the addition of polystyrene in the catalytic pyrolysis of torrefied wood at $600^{\circ} \mathrm{C} .{ }^{13}$

The acidity of the catalyst is very important in the catalytic cracking process, especially Bronsted acid, because it is related to the yield and the selectivity of the cracking product. ${ }^{19}$ Al-MCM-41 could be considered as one of the most promising catalysts for the co-pyrolysis process as it has a high surface 
RASĀYAN J. Chem.

64-71| Special Issue | 2021

area, mesopore diameter, and medium acidity, which allowed large oxygenated molecules to be cracked into smaller molecules ${ }^{8,9}$. Moreover, it has been demonstrated that Al-MCM-41 catalyst has a high selectivity on the gasoline range in the co-pyrolysis of biomass and plastic waste, which is beneficial for bio-gasoline production. ${ }^{19-21}$

In this study, the production of bio-gasoline from candlenut oil biodiesel (Aleurites moluccana) was carried out through a catalytic pyrolysis process using Al metal modified MCM-41 catalyst and ceramic supporting solids. Different candlenut oil biodiesel to PS ratios was used to investigate the effect of feedstock ratios on the gasoline fraction composition and the physical properties of the fuel blend include density, viscosity, calorific value, and octane number.

\section{Catalyst Preparation and Characterization}

\section{EXPERIMENTAL}

Ceramic insulators from spark plug were ground and sieved using mesh filter 100 to get a uniform size of ceramic powder. Al-MCM-41 catalysts obtained from previous study ${ }^{22}$ by the hydrothermal process were physically mixed with ceramic powder by the mass ratio of $7: 3$ and then put in an oven at $120^{\circ} \mathrm{C}$ for an hour to eliminate moisture. After being cooled, its characteristics were analyzed. X-Ray Diffraction (XRD) was carried out with $\mathrm{Cu} K \alpha$ radiation to examine the phase structure of the catalyst with $2 \theta$ from 0 $-10^{\circ}$. The surface morphology was analyzed by scanning electron microscopy (SEM FEI Quanta 20F). Meanwhile, the pore size and porosity of the catalyst were determined using $\mathrm{N}_{2}$ adsorption-desorption method (MicromeriticsTriStar II 3020 Automatic Physisorption Analyzer). The catalyst was vacuumed at $300^{\circ} \mathrm{C}$ for 1 hour to remove the trapped gas. The Brunauer-Emmett-Teller equation was used to calculate the surface area, $\mathrm{p} /$ po $=0.05-0.25$. Pore volume was measured using Barrett-Joyner-Halenda (BJH) method. Acidity on the catalyst was calculated using Pyridine-Adsorption Fourier Transform Infrared (Pyridine-FTIR) method. The quantity of Bronsted and Lewis acid was calculated using eqns.-1 and 2, respectively.

$$
\begin{aligned}
& C(B)=\operatorname{IMEC}(B)^{-1} \times I A(B) \times \frac{\pi R^{2}}{W} \\
& C(L)=\operatorname{IMEC}(L)^{-1} \times \operatorname{IA}(L) \times \frac{\pi R^{2}}{W}
\end{aligned}
$$

\section{Catalytic Co-pyrolysis Experiment}

The ex-situ catalytic co-cracking process was performed in a stainless-steel bed reactor, as shown in Fig.1. Briefly, the system consisted of two independent chambers. One of the chambers was used for cracking feedstock, while another contained the catalyst bed for post-cracking reaction. Nine grams of catalyst pellets were arranged in 2 levels with glass wool and placed in the tubular reactor. Approximately 1000 gram of samples were cracked using $\mathrm{N}_{2}$ as the carrier gas and heated to a final temperature of $300^{\circ} \mathrm{C}$. The final temperature was maintained for 120 minutes. A condenser with water reflux was used to trap the condensable gas. The liquid and solid yields were calculated by weight, while the share of noncondensable gas was calculated by difference. Based on these, several co-cracking processes were performed at a varied ratio of feedstock: PS:COB 1:1, PS:COB 4:3, and PS:COB 2:1. Prior to the cocracking process, samples of PS oil and COB were carefully mixed to ensure the homogeneity of feedstock.

\section{Product Characterization}

Product characterization in this study was only focused on the liquid fractions. Qualitative analysis of the chemical composition was conducted by GC-MS QP2010S SHIMADZU. The interpretation of the mass spectra given by GC-MS analysis was based on automatic search in the NIST12 library. The hydrocarbon fractions are grouped into hydrocarbons below $C_{7}, C_{7}-C_{12}$ hydrocarbons, and hydrocarbons above $C_{12}$ to examine the selectivity toward gasoline range fraction. The physiochemical properties, including density, viscosity, calorific value, and octane number, were determined based on the test method as shown in Table-1. The results of these characteristics were compared with standard gasoline fuel based on SNI 3506: 2017. 
RASĀYAN J. Chem.

64-71| Special Issue | 2021

\section{Catalyst Characterization}

\section{RESULTS AND DISCUSSION}

The SAXRD (Small Angle X-Ray Diffraction) pattern of the prepared catalyst is shown in Fig.-2. AlMCM-41 shows a sharp peak in the range $2 \theta=1.86-2.42^{\circ}$ and two wide peaks with low intensity in the range $2 \theta=2.74-3.85^{\circ}$ and $2 \theta=3.89-4.87^{\circ}$ which correspond to the reflection plane (100), (110), and (200), respectively. These peaks are the characteristic peaks of a highly ordered hexagonal arrangement of mesoporous materials. The mixing of the alumina oxide ceramic powder physically from the spark plug insulator waste material in the sample did not damage the MCM-41 hexagonal structure because the peak characteristics were still persisted without any shifting. However, a sharp decrease in peak intensity was observed after the addition of ceramic powder.

Table-1: Physical Characterization Test Methods

\begin{tabular}{c|c}
\hline Parameter & Method \\
\hline Density & ASTM D 4052 \\
\hline Viscosity & ASTM D 445 \\
\hline Caloric Value & ASTM D 4809-13/IP12 \\
\hline RON & ASTM D 2699 \\
\hline
\end{tabular}

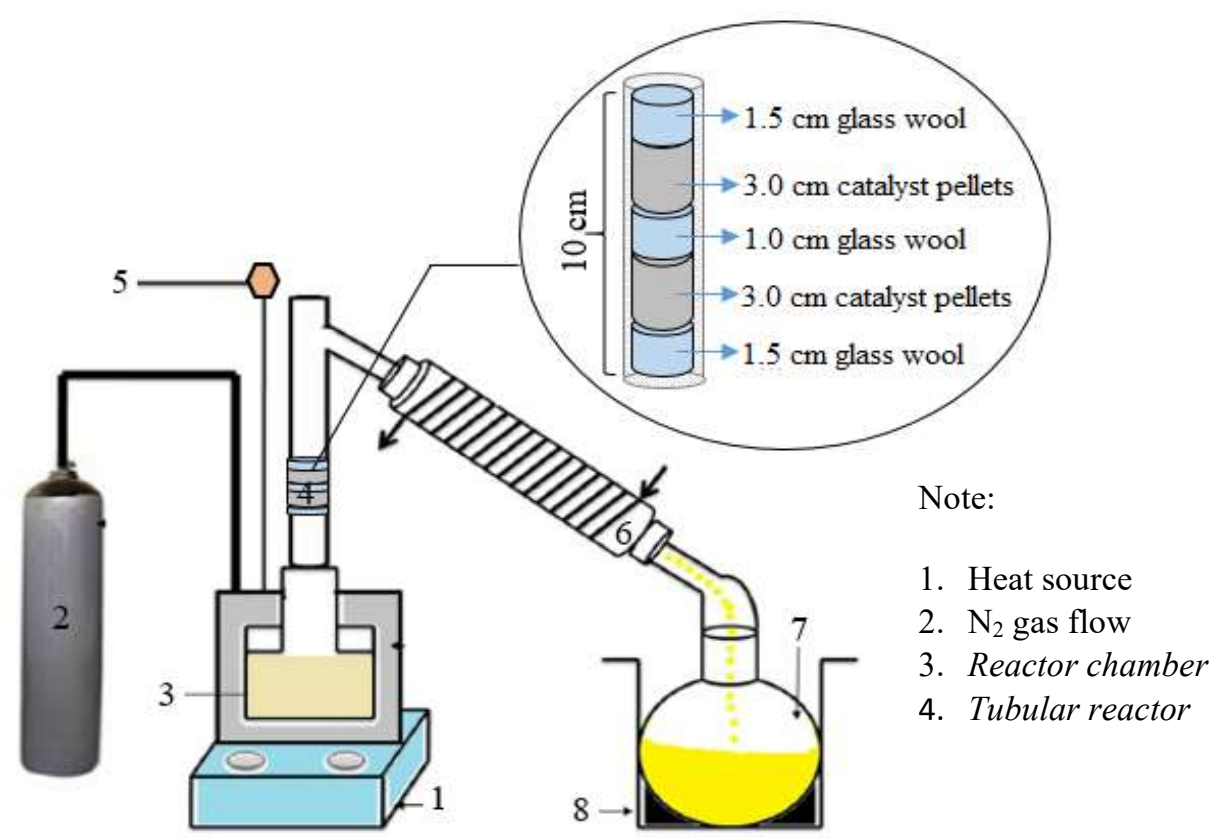

5. Thermometer

6. Condenser

7. Collecting flask

8. Water/ice bath

Fig.-1: Co-cracking Reactor Design

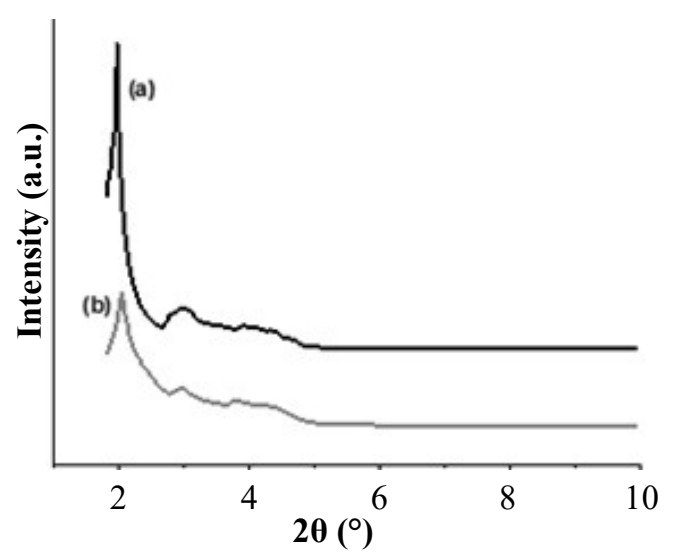

Fig.-2: SAXRD Difractogram of (a) Al-MCM-41 and (b) Al-MCM-41/ceramic

PRODUCTION OF BIO-GASOLINE

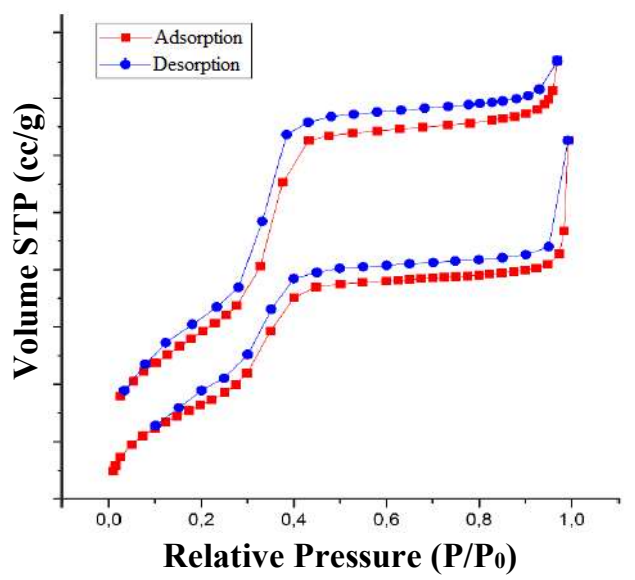

Fig.-4: $\mathrm{N}_{2}$ adsorption-desorption isotherm graph of (a) Al-MCM-41 and (b) Al-MCM-41/ceramic

A. Nurfitriyah et al. 
RASĀYAN J. Chem.

64-71| Special Issue | 2021

The morphology of Al-MCM-41 and Al-MCM-41/ceramic was shown in Fig.-3. Based on the SEM micrograph, it can be seen that Al-MCM-41 and Al-MCM-41/ceramic catalysts show particle agglomeration with a hexagonal structure that corresponds to the morphological characteristics of the MCM-41 material. The addition of alumina ceramic powder particles is indicated by the presence of agglomeration of particles in the form of sheets attached to Al-MCM-41 particles. Thus, it can be concluded that there is no structural damage of the Al-MCM-41 catalyst after the physical mixing of alumina oxide ceramic powder because no significant morphological differences were observed.

(a)

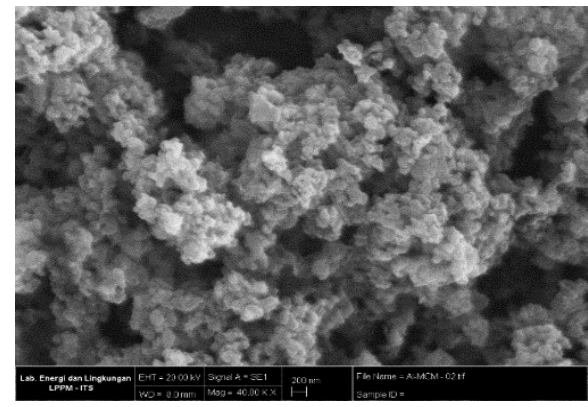

(b)

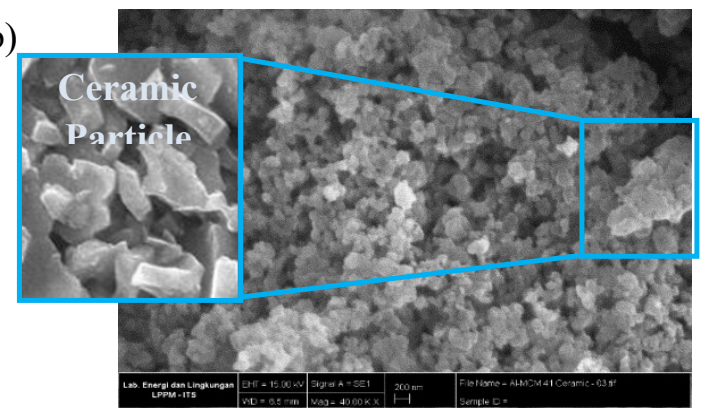

Fig.-3: SEM micrograph from catalyst (a) Al-MCM-41 and (b) Al-MCM-41/ceramic

Figure-4 shows the isothermal graph of the $\mathrm{N}_{2}$ gas adsorption-desorption from the prepared catalyst. The isotherm shapes of the two catalyst samples, Al-MCM-41 and Al-MCM-41 / ceramic were similar to those of the highly ordered MCM-41 mesoporous material. This shows that the pore characteristics of the aluminosilicate samples have not been damaged, as shown by the XRD pattern. The addition of alumina ceramic results in a higher surface area and pore volume. The value increases from 419.93 to 490.665 $\mathrm{m}^{2} / \mathrm{g}$ and 0.50 to $0.547 \mathrm{cc} / \mathrm{g}$, respectively. However, the total number of acid sites obtained from the FTIR analysis of pyridine decreased with the addition of alumina ceramic powder, as given in Table-2. The pyridine adsorption FTIR spectrogram is shown in Fig.-5.

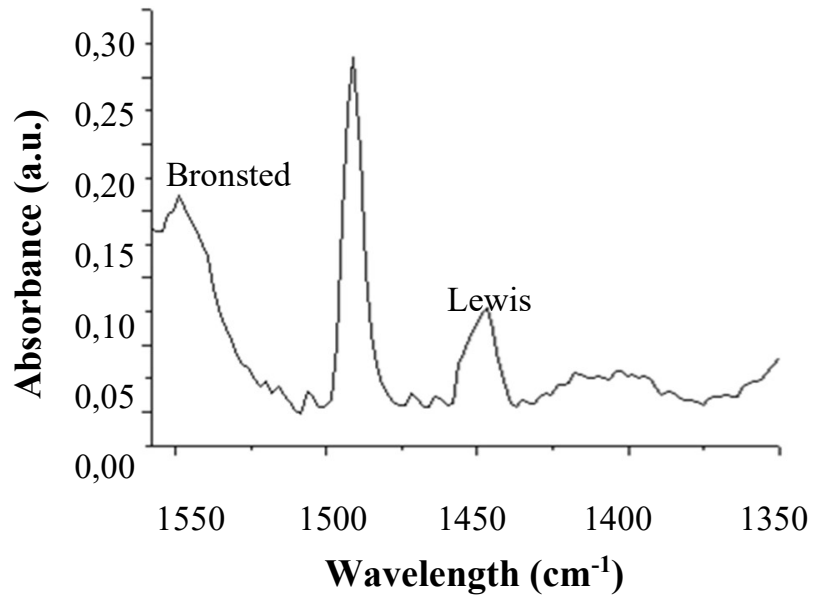

Fig.-5: FTIR Spectrogram for pyridine adsorption of Al-MCM-41/ceramic

Table-2: The Acidity Properties of the Catalyst

\begin{tabular}{l|c|c}
\hline $\begin{array}{c}\text { Number of acid } \\
\text { site }(\mathrm{mmol} / \mathrm{g})\end{array}$ & Al-MCM-41 & $\begin{array}{c}\text { Al-MCM- } \\
41 / \text { ceramic }\end{array}$ \\
\hline Lewis & 0.0386 & 0.0311 \\
\hline Bronsted & 0.0670 & 0.0342 \\
\hline Total acid site & 0.1056 & 0.0653 \\
\hline
\end{tabular}

\section{Catalytic Pyrolysis Process}

Catalytic pyrolysis of candlenut oil biodiesel and PS was performed using Al-MCM-41/ceramics catalyst at $300^{\circ} \mathrm{C}$ in the following three different feedstock ratios (PS: COB 1:1, 4:3, and 2:1). As indicated in the 
RASĀYAN J. Chem.

64-71| Special Issue | 2021

literature, catalytic pyrolysis produced three major products, including liquid hydrocarbon, coke, and noncondensable gas. ${ }^{23}$ The product yield from catalytic co-pyrolysis of CBO and PS at various feedstock ratios was given in Table-3.

Table-3: Yield of Catalytic Co-pyrolysis CBO and PS

\begin{tabular}{c|c|c|c|c}
\hline No. & Feedstock Ratio & $\begin{array}{c}\text { The yield of Liquid } \\
\text { Hydrocarbon }(\%)\end{array}$ & $\begin{array}{c}\text { The yield of Coke } \\
(\%\end{array}$ & $\begin{array}{c}\text { The yield of Non- } \\
\text { Condensable Gas }(\%)\end{array}$ \\
\hline 1. & PS:COB $1: 1$ & 64.6 & 23.4 & 12.0 \\
\hline 2. & PS:COB 4:3 & 71.6 & 15.9 & 12.8 \\
\hline 3. & PS:COB $2: 1$ & 80.4 & 6.1 & 13.5 \\
\hline
\end{tabular}

Note: $\mathrm{COB}=$ Candlenut Oil Biodiesel

In general, increasing PS ratio in the reactant mixture led to an increase in the liquid hydrocarbon yield from $64.6 \%$ to $80.4 \%$ and a decrease in the coke yield from $23.4 \%$ to $6.1 \%$. Similar findings were demonstrated by other studies on co-pyrolysis of biomass and polystyrene. ${ }^{24-26}$ These facts could happen because PS is rich in volatile matter and has negligible fixed carbon. ${ }^{25}$ The higher PS ratio, the more volatile compounds existed to give more pyrolysis vapors. These would then be condensed into liquid products, thus increasing the yield of liquid hydrocarbon. Moreover, PS could act as a hydrogen donor during catalytic pyrolysis of candlenut oil biodiesel. The free radicals generated from this process will provoke cross-reaction $\mathrm{COB}$ and PS. These reactions have a great potential to a breakdown of the functional group associated with the methyl ester structure of candlenut oil biodiesel which suppresses the low molecular weight compounds and the higher molecular compounds that appear as gas and liquid phases. ${ }^{25}$

\section{Influence of Feedstock Ratio on Product Composition}

Obtained liquid hydrocarbon comprised of complex mixture of organic compound which could be depicted in the appearance of several peaks in GC-MS chromatogram as shown in Fig.-6. Compound with the highest peak areas was chosen, integrated, and their percent area was determined quantitatively based on the peak area. ${ }^{13}$ The composition of the hydrocarbon fraction for each feedstock ratios was summarized in Fig.-7. It could be observed that Al-MCM-41/ceramic catalyst used in co-pyrolysis of COB and PS shows high selectivity on gasoline fraction $\left(\mathrm{C}_{7}-\mathrm{C}_{12}\right)$ owing to the fact that gasoline fraction represented the major constituent of the liquid product for all feedstock ratios variation. The presence of the Bronsted acid site, as well as Lewis acid site in Al-MCM-41/ceramics, promote the cracking reaction of long-chain hydrocarbons into shorter chain hydrocarbons which enhance the formation of gasoline fraction. ${ }^{27}$ In addition, other hydrocarbon fractions such as diesel fraction (above $\mathrm{C}_{12}$ ) and light hydrocarbon fraction $\left(<\mathrm{C}_{7}\right)$ were also identified in the liquid product, nevertheless in smaller proportion.

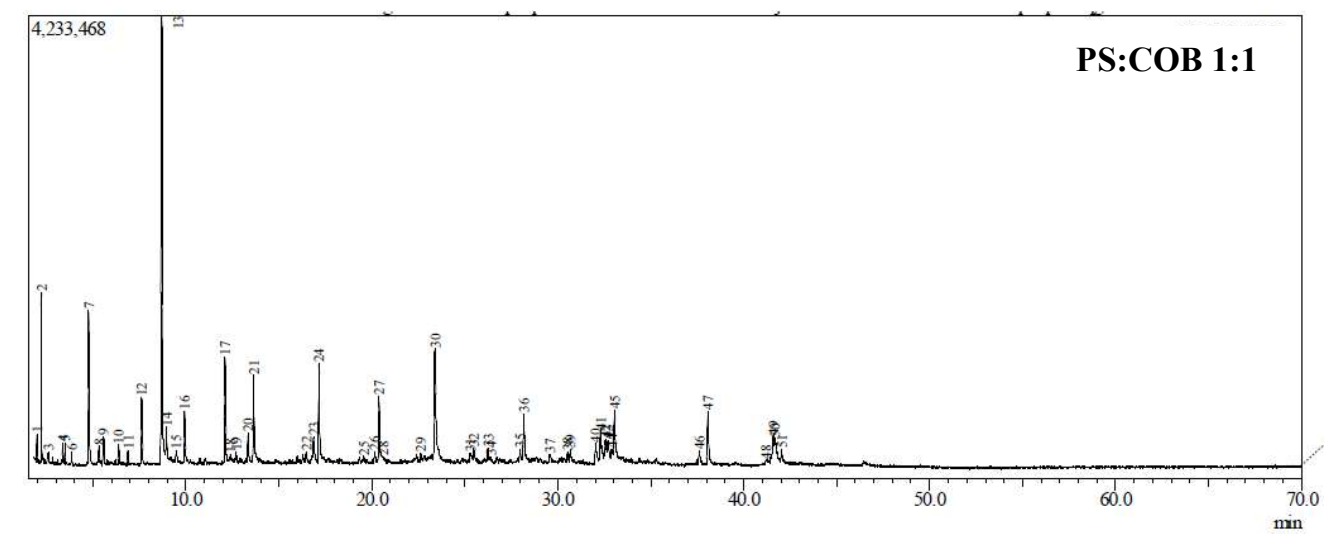

Fig.-6. GC-MS chromatogram sample of the liquid hydrocarbon from catalytic co-pyrolysis of COB and PS

In contrast to the trend of increasing liquid hydrocarbons yield with an increase of PS mixing ratio, the composition of gasoline fraction $\left(\mathrm{C}_{7}-\mathrm{C}_{12}\right)$ tends to decrease. As indicated in the literature, pyrolysis of PS produced oil which mostly consisted of aromatics and styrene-derived compounds. ${ }^{17}$ The longer 
RASĀYAN J. Chem.

64-71| Special Issue | 2021

reaction time of catalytic co-pyrolysis in a fixed-bed reactor would cause re-polymerization of styrenederived compound or oligomerization of aromatics and result in a long chain of hydrocarbons. Hence, at a higher PS mixing ratio, the formation of diesel fractions (above $\mathrm{C}_{12}$ ) was favored and the yield of gasoline fraction was reduced. The highest composition of gasoline fraction in the liquid product was obtained from the feedstock ratio of PS:COB 1:1, which reached $81.17 \%$.

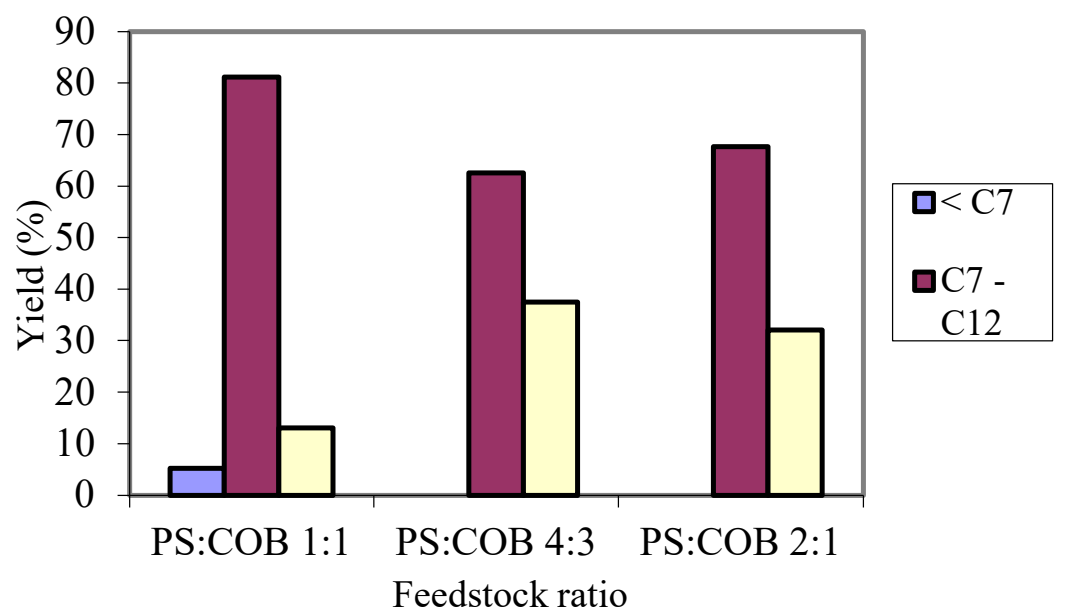

Fig.-7: Product Composition of Liquid Hydrocarbon

\section{Physical Characteristics of Fuel Blend}

The properties of the obtained liquid were investigated as a fuel blend with commercial gasoline and compared with the gasoline fuel standard based on SNI 3506: 2017. Table-4 represents the physical properties of the fuel blend obtained from catalytic co-pyrolysis of COB and PS. The density of fuel blends increased gradually with the addition of PS ratio and they were found to be higher than commercial gasoline. The density at 2:1 ratio was the highest compared to all ratios with the value of $0.760 \mathrm{~g} / \mathrm{cm}^{3}$. On the other hand, there was no linear relation of feedstock ratio with viscosity. The kinematic viscosity value obtained in this study was in the range of $0.33 \mathrm{cSt}$ to $0.49 \mathrm{cSt}$. These viscosities were too low, which somehow need further upgrading in terms of its application for vehicle fuel. Theoretically, kinematic viscosity manifests spray pattern and atomization behavior in a combustion chamber. Liquid fuel with too high or too low viscosity will cause poor atomization and leakage at the fuel injector, respectively, which in the latter lead to poor engine performance. ${ }^{25}$

Table-4: Physical Properties of Fuel Blend

\begin{tabular}{l|c|c|c|c|c}
\hline \multicolumn{1}{c|}{ Parameter } & PS:COB 1:1 & PS:COB 4:3 & PS:COB 2:1 & $\begin{array}{c}\text { Commercial } \\
\text { Gasoline }\end{array}$ & $\begin{array}{c}\text { SNI } \\
3504: 2017\end{array}$ \\
\hline $\begin{array}{l}\text { Density at } 15^{\circ} \mathrm{C} \\
\left(\mathrm{g} / \mathrm{cm}^{3}\right)\end{array}$ & 0.751 & 0.753 & 0.760 & 0.712 & $0.71-0.77$ \\
\hline $\begin{array}{l}\text { Kinematic viscosity at } \\
40^{\circ} \mathrm{C}(\mathrm{cSt})\end{array}$ & 0.49 & 0.33 & 0.39 & 0.28 & $<1.17$ \\
\hline $\begin{array}{l}\text { Calorific value } \\
(\mathrm{kcal} / \mathrm{kg})\end{array}$ & 16.663 & 20.843 & 27.208 & 10.595 & 10.150 \\
\hline $\begin{array}{l}\text { Octane number } \\
(\mathrm{RON})\end{array}$ & 100.5 & 97.8 & 98.1 & 92.2 & Min. 88 \\
\hline
\end{tabular}

The blending of the obtained liquid fuel in the commercial gasoline fuel gave rise to the calorific values significantly. Commercial gasoline has a calorific value of $10.595 \mathrm{kcal} / \mathrm{kg}$ and then increases to 16.663 $\mathrm{kcal} / \mathrm{kg}, 20.843 \mathrm{kcal} / \mathrm{kg}$, and $27.208 \mathrm{kcal} / \mathrm{kg}$ for PS:COB ratio of $1: 1,4: 3$, and $2: 1$ successively. The observed results confirmed that calorific value was affected by the feedstock ratio of candlenut oil biodiesel and polystyrene in a particular way. The high calorific value of co-pyrolytic oil could be associated with the high composition of aromatic-derived products from pyrolysis of polystyrene, which possessed high energy content. ${ }^{26}$ Moreover, the research octane number (RON) of fuel blends was 
RASĀYAN J. Chem.

64-71| Special Issue | 2021

observed to be higher than commercial gasoline. However, no such direct relation of feedstock ratio with RON was perceived. The highest octane number was RON 100.5, which was obtained at PS:COB ratio of $1: 1$.

Considering the result of physical properties evaluated in Table-4, all liquid oil obtained from catalytic co-pyrolysis of PS:COB with different feedstock ratios are in accordance with gasoline quality standard, SNI 3506:2017. Thus, it may be suggested as potential alternative fuel or additive for gasoline-range fuel.

\section{CONCLUSION}

In this study, catalytic co-pyrolysis of candlenut oil biodiesel and polystyrene waste at various feedstock ratios (1:1, 4:3, and 2:1) were successfully carried out using Al-MCM-41/ceramics catalyst. The results exhibit that a higher ratio of PS in the mixture contributed toward a higher yield of liquid hydrocarbon, with the yield in the range of $64.6 \%$ to $80.4 \%$. The composition of the hydrocarbon fraction and the quality of the resulting liquid oil were strongly influenced by the feedstock ratio of PS:COB. The highest composition of gasoline fraction $\left(\mathrm{C}_{7}-\mathrm{C}_{12}\right)$ was obtained at an optimum feedstock ratio of $1: 1$ at $81.17 \%$. The resulting biofuel exhibits promising physical properties in terms of higher calorific value (16.663 $\mathrm{kcal} / \mathrm{kg}-27.208 \mathrm{kcal} / \mathrm{kg}$ ) and higher octane number $(97.8-100.5)$ compared to commercial gasoline. Moreover, evaluation of physical properties confirmed that obtained biofuel for all feedstock ratio has meet gasoline quality standard SNI 3506:2017, which make them potential as an alternative fuel on gasoline range.

\section{ACKNOWLEDGEMENT}

The authors gratefully acknowledge the Ministry of Research, Technology, and Higher Education (Ristekdikti) of Republic Indonesia for the financial grant via National Competitive Research on Thesis Magister Research scheme.

\section{REFERENCES}

1. B.B. Uzoejinwa, X. He, S. Wang, A. E. Abomohra, Y. Hu, and Q. Wang, Energy Conversion and Management, 163, 468(2018), https://doi.org/10.1016/j.enconman.2018.02.004

2. H. Zhang, R. Xiao, J. Nie, B. Jin, S. Shao, and G. Xiao, Bioresource Technology, 192, 68(2015), http://dx.doi.org/10.1016/j.biortech.2015.05.040

3. S. Karnjanakom, T. Suriya-umporn, A. Bayu, S. Kongparakul, C. Samart, C. Fushimi, A. Abudula, and G. Guang, Energy Conversion and Management, 142, 272(2017), http://dx.doi.org/10.1016/j.enconman.2017.03.049

4. J.L. Sihombing, A.L. Pulungan, M. Zubir, Jasmidi, A.A. Wibowo, S. Gea, B. Wirjosento, and Y.A. Hutapea, Rasayan Journal of Chemistry, 12(1), 205(2019), http://dx.doi.org/10.31788/RJC.2019.1215036

5. M. Mahlinda and M. Busthan, Agritech, 37(3), 295(2017), http://doi.org/10.22146/agritech.11263

6. M.A. Shaah, F. Allafi, Md.S. Hossain, A. Alsaedi, N. Ismail, M.O.A. Kadir, M.I. Ahmad, International Journal of EnergyResearch, 45, 1(2021), https://doi.org/10.1002/er.6446

7. M.R.P. Cabral et al., Industrial Crops and Products, 85, 109(2016), http://dx.doi.org/10.1016/j.indcrop.2016.02.058

8. D.K. Ratnasari, W. Yang, and P.G. Jönsson, Journal of Analytical and Applied Pyrolysis, 134, 454(2018), https://doi.org/10.1016/j.jaap.2018.07.012

9. E.F. Iliopoulou, E.V. Antonakou, S.A. Karakoulia, I.A. Vasalos, A.A. Lappas, K.S. Triantafyllidis, Chemical Engineering Journal, 134(1-3), 51(2007), https://doi.org/10.1016/j.cej.2007.03.066

10. W. Ma, B. Liu, R. Zhang, T. Gu, X. Ji, L. Zhong, G. Chen, L. Ma, Z. Cheng, X. Li, Applied Energy, 217, 233(2018), https://doi.org/10.1016/j.apenergy.2018.02.036

11. Y.K. Park, B. Lee, H.W. Lee, A. Watanabe, J. Jae, Y.F. Tsang, and Y.M. Kim, Chemical Engineering Journal, 378, 122151(2019), https://doi.org/10.1016/j.cej.2019.122151

12. W.A. Wan Mahari, C.T. Chong, C.K. Cheng, C.L. Lee, K. Hendrata, P.N.Y. Yek, N.L. Ma, and S.S. Lam, Energy, 162, 309(2018), https://doi.org/10.1016/j.energy.2018.08.002

13. E.B. Hassan, I. Elsayed, and A. Eseyin, Fuel, 174, 317(2016), http://dx.doi.org/10.1016/j.fuel.2016.02.031 
RASĀYAN J. Chem.

64-71| Special Issue | 2021

14. Y. Wang, L. Dai, D. Fan, L. Chao, Y. Zhou, Y. Zhao, Y. Liu, and R. Ruan, Waste Management, 61, 276(2017), http://dx.doi.org/10.1016/j.wasman.2017.01.010

15. F. Abnisa and W.M.A. Wan Daud, Energy Conversion and Management, 87, 71(2014), http://dx.doi.org/10.1016/j.enconman.2014.07.007

16. Y.A. Aubakirov, L. R. Sassykova, Zh. Kh. Tashmukhambetova F. Zh. Akhmetova, S. Sendilvelan , K.O. Sharipov, Sh. N. Kubekova, A.A. Batyrbayeva, R.N. Azhigulova, R. G. Ryskaliyeva, A.K. Zhussu, Rasayan Journal of Chemistry, 12(4), 1701(2019), http://dx.doi.org/10.31788/RJC.2019.1245435

17. O. Sanahujo-Parejo, A. Veses, M.V. Navarro, J.M. López, R. Murillo, M.S. Callén, and T. García, Chemical Engineering Journal, 377, 120246(2019), https://doi.org/10.1016/j.cej.2018.10.183

18. H. Zhang, R. Xiao, J. Nie, B. Jin, S. Shao, and G. Xiao, Bioresource Technology, 192, 68(2015), http://dx.doi.org/10.1016/j.biortech.2015.05.040

19. Y. Chi, J. Xue, J. Zhuo, D. Zhang, M. Liu, dan Q. Yao, Science of the Total Environment, 633, 1105(2018), https://doi.org/10.1016/j.scitotenv.2018.03.239

20. H. Juwono, W. Trisunary, L. Efiyanti, S.I. Bahri, K. Amri, A. Assari, S. Suprapto, and Y.L. Ni'mah, Rasayan Journal of Chemistry, 14(2), 1049(2021), http://dx.doi.org/10.31788/RJC.2021.1426056

21. H. Juwono, F.S. Pamungkas, A. Elliyanti, A.H. Dermawan, and A. Nurfitriyah, IOP Conference Series: Earth and Environmental Science, 456, 012006(2020), https://doi.org/10.1088/1755$\underline{1315 / 456 / 1 / 012006}$

22. H. Juwono, Triyono, Sutarno, E.T. Wahyuni, I. Ulfin, and F. Kurniawan, Indonesian Journal of Chemistry, 17, 316(2017), https://doi.org/10.22146/ijc.24180

23. S.D.A Sharuddin, F. Abnisa, W.M.A. Wan Daud, and M.K. Aroua, Energy Conversion and Management, 115, 308(2016), https://doi.org/10.1016/j.enconman.2016.02.037

24. F. Abnisa, W.M.A. Wan Daud, S. Ramalingam, M.N.B.M. Azemi, and J.N. Sahu, Fuel, 108, 311(2013), http://dx.doi.org/10.1016/j.fuel.2013.02.013

25. B. Muneer, M. Zeeshan, S. Qaisar, M. Razzaq, and H. Iftikhar, Journal of Cleaner Production, 237, 117762 (2019), https://doi.org/10.1016/j.jclepro.2019.117762

26. K.P. Shadangi and K. Mohanty, Fuel, 153, 492(2015), http://dx.doi.org/10.1016/j.fuel.2015.03.017

27. H.K.G. Singh, S. Yusup, A.T. Quitain, B. Abdullah, M. Ameen, M. Sasaki, T. Kida, and C.K. Wai, Environment Research, 186, 109616(2020), https://doi.org/10.1016/j.envres.2020.109616

[RJC-6350/2021] 